\title{
Impact of Industrial Shut Down and Land Use Change in Chaliyar Basin
}

\author{
Asima Nusrath (Corresponding author) \\ Department of Studies in Geography, Manasagangotri University of Mysore \\ PO box 570 006, Mysore, Karnataka, India \\ Tel: 91-998-652-5716 E-mail: n_asima@yahoo.com \\ A. M. Shabeer \\ Department of Studies in Geography, Manasagangotri University of Mysore \\ PO box 570 006, Mysore, Karnataka, India \\ Tel: 91-974-662-5513Ｅ-mail: shabeeramb@gmail.com
}

Received: May 12, $2010 \quad$ Accepted: May 21, 2010 doi:10.5539/jgg.v3n1p247

\begin{abstract}
The gradual migration of local labor for jobs abroad has made a remarkable impact on the land use in the local region. The large scale migration was chiefly the outcome of unemployment in the local region as a result of the shutdown of the rayon industry which was the only source of income to the local village community. Two phenomena were observed parallel since 2001. First, the migration pattern of labor force in the study area, and second, the changes in land use pattern. In this background of the problem it is interesting to observe the land use changes through remote sensing during different time periods.
\end{abstract}

Keywords: Industrial shut down, Migration, Land use change

\section{Introduction}

The rayon industry is popularly characterized as causing distress on the health of people and environment. A large number of rayon industries worldwide have shut down as a result of the peoples opposition upon their continuation. Mitsubishi Rayon (1992), Anderson, Patricia Ann (1993), Frances Carr (2001), Frederick Noronha (1999) have reported to this effect. The Global environmental group Greenpeace has been actively functioning to identify such industries and work against them. In India the Greenpeace group has backed for the closure of the Mavoor rayon factory, and has demanded an adequate compensation for the damage done to the environment and residents around this region.

The Gwalior Rayon's started production of pulp and fiber for textile in 1960 which caused a rapid change in the life style of native population followed by a tremendous regional development. The Chaliyar River which flows near the factory was severely polluted by this industry. The Gwalior Rayon's besides, has created wide spread impact reduction in agricultural productivity in the region. The overall influence was so critical that it aroused great opposition to the operation and continuation of this industry. With popular opposition both from the government and the people the industry ultimately closed in 2002 . The primary and immediate impact of the shutdown was observed on outmigration of people in search of jobs and the secondary impact was realized on the land use change.

The pulp and fiber factory at Mavoor is the biggest private sector unit in Kerala. Mavoor is a village in Kozhikode district located $20 \mathrm{~km}$ away from Calicut city in Kerala, India. Mavoor was like any other undeveloped village at the vicinity of lush evergreen forest of the Western Ghats, depending chiefly on plantation crops. The basic raw materials for pulp manufacture are bamboo and eucalyptus. The company acquired 30,000 acres of forest land to raise industrial plantation of eucalyptus. Every year 2,500-3000 acres of natural forests were turned into eucalyptus jungle. There was a ruthless exploitation of forests leading to a diminution in the supply of bamboo and eucalyptus and as a consequence shortage in the supply of raw material.

The industry consists of a rayon grade pulp division, a viscose staple fiber division and a paper plant. The pulp division employs over 4,000 workers and is the most significant in terms of employment. The fiber division 
employs 500 and the paper division employs around 1000 workers. Apart from nearly 6000 workers who are directly employed, about 10,000 people are indirectly dependent on the factory for their livelihood Mohan (1988).

After the opening of the rayon industry the land use structure of the region has underwent enormous change causing great impact on the natural vegetation, and agricultural lands. The industry was also a source of severe environmental hitch to the region's air, and water which lead to the ultimate shutdown.

As a result of the shutdown, all the local population became unemployed. They by and large shifted out for better jobs into the Middle East countries. This study analyzes the impact caused from the shutdown of rayon industry on land use change. The application of remote sensing and image processing technologies are able to answer not only questions related to the spatial land use patterns but also precisely estimate the extent of land in various land uses and their distribution and change over time.

\subsection{Objectives}

To assess the impact of industrial shutdown on land use change.

\subsection{Study area}

The Mavoor rayon industry is located in the northern part of the Malappuram district and southern part of the Kozhikode district, the Chaliyar river act as a natural divide between the two districts. The study area is located $11^{\circ} 14^{\prime} 20^{\prime \prime} \mathrm{N}-11^{\circ} 16^{\prime} 20^{\prime \prime} \mathrm{N}$ latitude and $75^{\circ} 56^{\prime} 25^{\prime \prime} \mathrm{E}-75^{\circ} 58^{\prime} 25^{\prime \prime}$ E longitude. The Chaliyar River is draining the Mavoor region, which is flowing from the Western Ghats and debouching into the valleys and flowing to join the Arabian Sea.

For the purpose of intensive analysis the study area is examined at two levels, one at a macro scale taking into consideration the entire region which is affected by the industrial shut down, covering a total geographical area of $12.358 \mathrm{sq} \mathrm{Km}$. The second level of analysis is done at a micro level, selecting the region which is the actual site of the industry, which is located in the central part of the entire region. This micro region covers an area of 5 Sq.Kms. The land use in this region is mostly the industrial premises, the working men's quarters, and the industrial waste dumps and tanks filled with polluted greasy waste water. The Challiyar river flows beside the industrial region.

\subsection{Materials and methods}

The base map of the study area was prepared using survey of India topographical sheets bearing Nos. 49M15, 49M16, 58A3 and 58A4 of 1:50,000 scales chiefly covering the Chaliyar river basin.

Population migration data was obtained from Economics and Statistics District office, Calicut and Malappuram for the period 1971-2001.

The secondary data was collected for two Panchayath (group of villages) covered in the study area. Field survey was conducted to collect data related to migration, sources of income, type of crops grown, etc. and maps were prepared using ArcGIS.

The IRS 1C, and 1D satellite images were used to obtain Landuse data. The nature of land use change was monitored for a period of 10 years, ie., five years before the shutdown and five years after the shut down. And 1995 is taken as a base year followed by 2000, 2003, and 2005.

Satellite image data was prepared as follows:

\subsubsection{Atmospheric correction}

All images were checked for atmospheric effects, and scene illumination. The simple haze correction was performed in order to remove the atmospheric disturbance in each image.

\subsubsection{Image registration}

All images were geometrically rectified into the UTM coordinate system using ground control points (GCP's) that were visibly distinct. A least squares method was used to calculate the transformation from the toposheet to image. A first order linear transformation was used. The acceptable RMS error threshold value was $<0.9$ for all the multispectral images.

\subsubsection{Land use/land covers type classification}

The images were geo referenced with the help of topographical map. Supervised classification was performed for six different classes. The number of classes was kept to a lesser number for the reason that the land use land cover in this region is monotonously predominated by water bodies, agriculture and plantation farms. For the 
purpose of checking the ground truth for different land use classes, a test of accuracy was performed through kappa statistics.

The accuracy and ground truth was assessed with the help of primary survey and other supporting maps such as toposheet, and Google earth. All the images were subjected to accuracy assessment and the Kappa statistics resulted from the satellite images for the years, 1995, 2000, 2003, and 2005 was 83.40. 86.90. 84.80 and 87.80 respectively. Owing to the high resolution and assisted by good ground verification the results of accuracy assessment showed good results with $<80 \%$. The results of accuracy assessment show three categories of assessment results.

First, the accuracy assessment shows that the error is accumulated between wet agricultural lands and grasslands. With an average Kappa index of 0.5 .

Second, the dry agricultural lands, scrub and rural settlements have shown a high degree of overlap, with a kappa index of 0.9 , for the reason being, all these features have very high reflectivity and brightness giving rise to discomfortibility in classification.

Third, the accuracy for other classes of land cover has shown very good distinguishable results. With a value of 0 , the land covers included in this class of land use are water bodies, settlement / built-up area, dry barren lands, open scrub. All these with a kappa index ranging 0 to 0.2 . Hence for our further analysis these land uses shall be taken in greater detail for further analysis.

\section{Migration pattern of Chaliyar river basin}

Out migration in Mavoor and the Mavoor industrial region has played an important role in the Kozhikode district in Kerala. Most of the people in this region are employed in industrial and trade activities in the Middle Eastern countries.

Table 1 explains the migration trend in the macro, and micro regions in the study area. After the starting of the rayon industry in 1961 the environment was not conducive to live in the surrounding areas of the industry. There was a rampant outmigration of people. The migration of people was generally to a proportion of 1: 50 . The local population was chiefly migrating to the neighboring areas within Kerala, Karnataka and Maharashtra for business and other economic activities. During the early 1980s there was a change in the nature of local population. Due to the availability of employment within the neighborhood region, large scale migration was reducing, and the majority of the working class of the residual population was employment with the Rayon industry.

During 1991 to 2000 there was a massive consciousness about the widespread distress. There were continuous agitations against the functioning of the industry, and was a sense of uncertainty about the continuation of the industry and the insecurity of employment. In the later part of the 1990s, a gradual trend was beginning towards international migration especially to the gulf countries for better income opportunities and improved standard of living. It was at this time that there were at least 2-3 persons who were working in the middle eastern countries from every family. The air, and water pollution had resulted in severe health problems, and the entire settlement was almost becoming bare of population, which had shifted to the nearest Panchayath in the surrounding regions.

Since 2001 there were tremendous increases in migration and it was at this time that the rayon company ultimately was shut down. And the entire population which had been still on the pay rolls was left without any employment. This led to an enormous amount of migration of working population.

\section{Impact of migration on land use change}

Figure 3 illustrates a comprehensive conceptual flow model of phenomena and of processes that were operational during an entire period spanning approximately 50 years leading to a tremendous change from a pure plantation economy to an semi industrial system and again leading to more diversification in the land use pattern.

The land use/land cover characteristics during 1995, reveals that the region is covered predominantly by mixed crops accounting to $34.9 \%$ of the total land area. The second largest area was occupied by paddy cultivation covering $28.4 \%$, and $16.3 \%$ of the total land area was used for other than agricultural purposes. And a very small proportion of area is used under built-up land.

In the second period the land cover pattern has gradually changed in favor of paddy cultivation, the total barren land has also reduced to a considerable proportion $-5.4 \%$ compared to 1995 . The built-up land is showing a marginal increase. It may be understood from the land use pattern that the land which was left barren during the time of regular employment is gradually being converted to economic use especially for the cultivation for food crops and other remunerative cash crops. 
Compared to the earlier two periods (1995 and 2000), in this period the land under built up class has shown an increasing trend. The increase is estimated to be about $8 \%$ in comparison to 1995 . The barren land has further reduced to $6.5 \%$ compared to 1995 . The paddy land has reduced by $5 \%$. The land use change may be summarized based on three issues. One, construction has increased due to the availability of cheap jobless labor force. And construction has also grown due to the inflow of wealth from the labor which has migrated to the Middle Eastern countries.

Second, the decline in the land under paddy cultivation may be attributed to the fact that, the government policy in Kerala is to increase rubber cultivation because of its economic significance. And it is the responsibility of the government to provide subsidized food through public distribution scheme. Hence most of the farmers switch over to cash crops instead of cultivating the staple non remunerative crops.

Third, the population which was engaged in non agricultural activities are more engaged in making economic use of the barren land by putting it to agricultural uses. Besides, the natural growth of population is also exerting pressure on increasing the land for the construction purposes.

The dominant changes found in 2005 period was that the land under paddy cultivation has further reduced, giving way to an increase in rubber plantation, the total land under paddy cultivation was only $15.9 \%$ of the total geographical area. The total land used for built-up purposes was $21.3 \%$, On the other hand the mixed cultivation is also reducing giving way for construction and rubber plantation. The barren land is rapidly vanishing compared to other period.

Figure 4 illustrates a graphical representation of the comparison between the Land use/ land cover changes in the Chaliyar river basin since 1995-2000, have been chiefly in agriculture, and other allied economic activities. Most of the land area under agriculture is changing commercial crops, during 1990-95, 28.4\% of the land area was utilized for paddy cultivation, but in 2005 it is observed that there is a sudden decline in the area covered for paddy. The total area under paddy is only $15.9 \%$ thereby a reduction of $12.5 \%$ of total land.

On the other hand the mixed cultivation in 1995 period was $34.9 \%$ and 2005 ; it has extended to $36.4 \%$ of the total land area during 2005. The mixed crops consist of areca nut, mango, coconut, and other fruits like banana, oranges etc. most of these crops in mixed crops are non remunerative compared to the commercial rubber cultivation. The total utilization for construction in 1995 periods was $11.1 \%$ which has increase to $21.3 \%$ in 2004-05. The barren land and marshy land also declined from 16.3\% in 1995 to 7.2 in 2005 . The sudden increase in construction has resulted due to increasing income especially from people employed in the gulf countries who have invested their savings chiefly in real estate and other economic activities.

\section{Land use change in the Micro region of the Chaliyar river basin}

The land use characteristics during 1995 period, reveals that a major portion of land is used for mixed cultivation and the next important land use was (19.8\%) built-up land. and the remaining $6.0 \%$ is under the water bodies. However on an average the changes in land cover have been the same in the micro area also. But there is a gradual shift in the total area covered under water bodies. Compared to 1995 the total area under water bodies was reduced to a proportion of $17.4 \%$ in 2000 , while the built up land has gradually increased.

The prominent changes found on the study area since 2005 period is water bodies, during this period the water bodies were totally absent. Most of these water tanks were used as dumping of the industrial waste, or used to drain out the water of the industrial waste. Remaining part of 32.1\% land area are used for the built-up purpose and $67.9 \%$ are used for the mixed cultivation. Compared to the earlier period the dominant changes in this region was the increased mixed cultivation and decreases of the water bodies and the built-up land.

\section{Conclusion}

It may be concluded that industrialization of any area brings with it, its own set of advantages and problems. Environmental changes are the reflections of the human activity. Man has to adjust with the changing conditions, change in the land use is the modification which man makes within the available alternatives at his disposal. It is also supposed to be the best selection man makes while struggling to make the best use of his opportunities.

\section{References}

Anderson, J. R., Ernest E. Hardy, John T. Roach \& Richard E. Witmer. (1976). A land use and land cover classification system for use with remote sensor data. United States Government Printing Office, Washington

Anderson, Patricia Ann. (1993). Environ. Impact Ind. Act. Proc. Ind. Agric. Impacts Hydrol. Environ., USA/CIS Jt. Conf. Environ. Hydrol. Hydrogeol, $2^{\text {nd }}$ edition. 
Edwin Martínez Martínez remote sensing techniques for land use classification of rio jauca watershed using ikonos images. [Online] Available at: http://gers.uprm.edu/geol6225/pdfs/e_martinez.pdf

Frances Carr. (2001). Indorayon's last gasp? Inside Indonesia-The environment, Edition, 65 ajn- Narch

Frederick Noronha. (2001). Environement news service, international daily newswire. India's 30-Year Eco-Crusade Shuts Rayon Plant. [Online] Available at: http://www.ens newswire.com/ens/sep1999/1999-09-15-02.asp

Jensen, J. R. (2005). Thematic Map Accuracy Assessment. Introductory Digital Image Processing-A Remote Sensing Perspective. Prentice Hall Series in Geographic Information Science. Series Editor- Keith C. Clarke. 3rd Edition. Chapter 13, Pp 495-515.

Judex, M., Thamm, M. J. \& G. Menz. (2006). Improving Land Cover Classification with a Knowledge Based Approach and Ancillary Data. Proceeding of the workshop of the EARSeL sig on Land Use and Land Cover, dated 28-30.

K. T. Ram Mohan \& K. Ravi Raman Kerala. (1988). Worker Rises against Indian Big Capital: Report on Rayons Workers' Struggle; Economic and Political Weekly, 23(27), 1359-1364. [Online] Available at: http://www.jstor.org/stable/4378698

Mitsubishi Rayon. (1992). Source: International Directory of Company Histories, Vol. 5. St. James Press.

Stefanov, W. L., Ramsey, M. S. \& P. R. Christensen. (2001). Monitoring Urban Land Cover Change: An Expert System Approach to Land Cover Classification of Semiarid to arid Urban Centers. Remote Sensing of Environment, 77, 173-185. doi:10.1016/S0034-4257(01)00204-8, http://dx.doi.org/10.1016/S0034-4257(01)00204-8 
Table 1. Accuracy assessment of the land use classification

\begin{tabular}{|c|c|c|c|c|}
\hline Class name & Producers accuracy & Reference total & User accuracy & Kappa statistics \\
\hline \multicolumn{5}{|l|}{ a) 1995 image } \\
\hline Water bodies & 60.71 & 28 & 77.27 & 0.77 \\
\hline Built-up land & 61.22 & 66 & 81.08 & 0.80 \\
\hline Mixed cultivation & 83.61 & 111 & 63.61 & 0.63 \\
\hline \multicolumn{3}{|c|}{ Overall Classification Accuracy } & \multicolumn{2}{|c|}{$83.40 \%$} \\
\hline \multicolumn{5}{|l|}{ b)2000 image } \\
\hline Water bodies & 81.82 & 19 & 90.00 & 0.66 \\
\hline Built-up land & 94.78 & 39 & 68.34 & 0.68 \\
\hline Mixed cultivation & 93.00 & 105 & 78.90 & 0.78 \\
\hline \multicolumn{3}{|c|}{ Overall Classification Accuracy } & \multicolumn{2}{|c|}{$86.90 \%$} \\
\hline \multicolumn{5}{|l|}{ c)2003 image } \\
\hline Water bodies & 55.56 & 54 & 83.33 & 0.83 \\
\hline Built-up land & 75.49 & 102 & 79.38 & 0.77 \\
\hline Mixed cultivation & 74.47 & 94 & 79.55 & 0.77 \\
\hline \multicolumn{3}{|c|}{ Overall Classification Accuracy } & \multicolumn{2}{|c|}{$84.80 \%$} \\
\hline \multicolumn{5}{|l|}{ d)2005 image } \\
\hline Water bodies & 100.0 & 18 & 72.00 & 0.71 \\
\hline Built-up land & 75.90 & 83 & 71.59 & 0.69 \\
\hline Paddy cultivation & 37.33 & 75 & 38.59 & 0.38 \\
\hline \multicolumn{3}{|c|}{ Overall Classification Accuracy } & \multicolumn{2}{|c|}{$87.20 \%$} \\
\hline
\end{tabular}

Table 2. Migrational pattern in Chaliyar river basin

\begin{tabular}{|l|c|c|c|c|}
\hline \multicolumn{5}{|c|}{ Migration pattern in Chaliyar river basin during 1971-2001 } \\
\hline \multicolumn{1}{|c|}{ Regions } & 1971 & 1981 & 1991 & 2001 \\
\hline $\begin{array}{c}\text { 1 person in every 50 } \\
\text { population }\end{array}$ & $\begin{array}{c}\text { 1 person in every 40 } \\
\text { population }\end{array}$ & $\begin{array}{c}\text { 1 person in every 20 } \\
\text { population }\end{array}$ & $\begin{array}{c}\text { 1 person in every 5 } \\
\text { population }\end{array}$ \\
\hline $\begin{array}{l}\text { Severely affected } \\
\text { region }\end{array}$ & 338 & 524 & 1188 & 5322 \\
\hline $\begin{array}{l}\text { Moderately } \\
\text { affected region }\end{array}$ & 225 & 349 & 792 & 3548 \\
\hline $\begin{array}{l}\text { Partially affected } \\
\text { region }\end{array}$ & 188 & 291 & 660 & 2957 \\
\hline
\end{tabular}

Source: Economics and Statistics District office, Calicut and Malappuram. 
Table 3. Land use land cover change in Chaliyar river basin since 1995-2005(sq.km)

\begin{tabular}{|c|c|c|c|c|c|c|c|c|c|}
\hline \multirow{2}{*}{ Land uses } & \multicolumn{2}{|c|}{ Land Cover } & \multirow{2}{*}{$\begin{array}{c}\% \text { of } \\
\text { change }\end{array}$} & \multicolumn{2}{|c|}{ Land Cover } & \multirow{2}{*}{$\begin{array}{c}\% \text { of } \\
\text { change }\end{array}$} & \multicolumn{2}{|c|}{ Land Cover } & \multirow{2}{*}{$\begin{array}{c}\% \text { of } \\
\text { change }\end{array}$} \\
\hline & 1995 & 2000 & & 1995 & 2003 & & 1995 & 2005 & \\
\hline Water bodies & 1.601 & 1.621 & $1.2 \%$ & 1.601 & 1.614 & $0.8 \%$ & 1.601 & 1.511 & $-5.62 \%$ \\
\hline Built-up land & 1.981 & 2.163 & $9.1 \%$ & 1.981 & 2.820 & $42.3 \%$ & 1.981 & 2.634 & $32.9 \%$ \\
\hline Mixed cultivation & 9.136 & 8.934 & $-2.2 \%$ & 9.136 & 8.284 & $-9.3 \%$ & 9.136 & 8.573 & $-6.2 \%$ \\
\hline $\begin{array}{c}\text { Classification } \\
\text { accuracy }\end{array}$ & 86.18 & $85.3 \%$ & & $85.3 \%$ & $86.9 \%$ & & $86.9 \%$ & $87.2 \%$ & \\
\hline Total land area & 12.718 & 12.718 & & 12.718 & 12.718 & & 12.718 & 12.718 & \\
\hline
\end{tabular}

Table 4. landuse land cover on the micro part during 1995-2005

\begin{tabular}{|c|c|c|c|c|c|c|c|c|c|}
\hline \multirow{2}{*}{ Land uses } & \multicolumn{2}{|c|}{ Land Cover } & \multirow{2}{*}{$\begin{array}{l}\% \text { of } \\
\text { change }\end{array}$} & \multicolumn{2}{|c|}{ Land Cover } & \multirow{2}{*}{$\begin{array}{l}\% \text { of } \\
\text { change }\end{array}$} & \multicolumn{2}{|c|}{ Land Cover } & \multirow{2}{*}{$\begin{array}{l}\% \text { of } \\
\text { change }\end{array}$} \\
\hline & 1995 & 2000 & & 1995 & 2003 & & 1995 & 2005 & \\
\hline Water bodies & 0.92 & 0.108 & $17.4 \%$ & 0.92 & 0.130 & $41.3 \%$ & 0.92 & 0 & $-100 \%$ \\
\hline Built-up land & 0.306 & 0.403 & $31.7 \%$ & 0.306 & 0.606 & $98.1 \%$ & 0.306 & 0.496 & $62 \%$ \\
\hline Mixed cultivation & 1.145 & 1.032 & $-9.9 \%$ & 1.145 & 0.807 & $-29.5 \%$ & 1.145 & 1.047 & $-8.6 \%$ \\
\hline $\begin{array}{l}\text { Classification } \\
\text { accuracy }\end{array}$ & 86.18 & $85.3 \%$ & & $85.3 \%$ & $86.9 \%$ & & $86.9 \%$ & $87.2 \%$ & \\
\hline Total land area & 1.543 & 1.543 & & 1.543 & 1.543 & & 1.543 & 1.543 & \\
\hline
\end{tabular}

Table 5. Land use differences in Macro and Micro regions

\begin{tabular}{|l|r|r|r|r|r|r|r|r|r|}
\hline \multirow{2}{*}{ Landuse } & \multicolumn{10}{|c|}{ Macro region } \\
\cline { 2 - 11 } & 1995 & 2000 & \% of change & 1995 & 2003 & \% of change & 1995 & 2005 & \% of change \\
\hline Water bodies & 1.601 & 1.621 & 1.2 & 1.601 & 1.614 & 0.8 & 1.601 & 1.511 & -5.62 \\
\hline Built-up land & 1.981 & 2.163 & 9.1 & 1.981 & 2.820 & 42.3 & 1.981 & 2.634 & 32.9 \\
\hline Mixed cultivation & 9.136 & 8.934 & -2.2 & 9.136 & 8.284 & -9.3 & 9.136 & 8.573 & -6.2 \\
\hline \multirow{2}{*}{ Landuse } & \multicolumn{10}{|c|}{ Micro region } \\
\cline { 2 - 12 } & 1995 & 2000 & \% of change & 1995 & 2003 & \% of change & 1995 & 2005 & \% of change \\
\hline Water bodies & 0.92 & 0.108 & 17.4 & 0.92 & 0.130 & 41.3 & 0.92 & 0 & -100 \\
\hline Built-up land & 0.306 & 0.403 & 31.7 & 0.306 & 0.606 & 98.1 & 0.306 & 0.496 & 62 \\
\hline Mixed cultivation & 1.145 & 1.032 & -9.9 & 1.145 & 0.807 & -29.5 & 1.145 & 1.047 & -8.6 \\
\hline
\end{tabular}




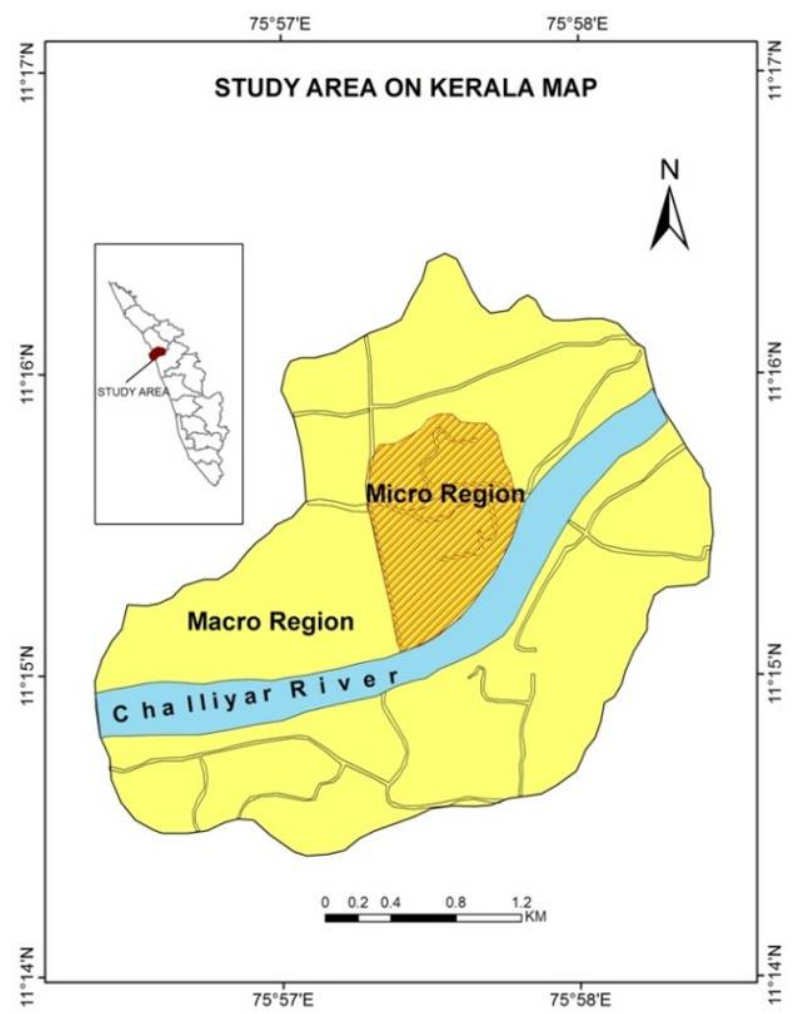

Figure 1. Study areas on Kerala map
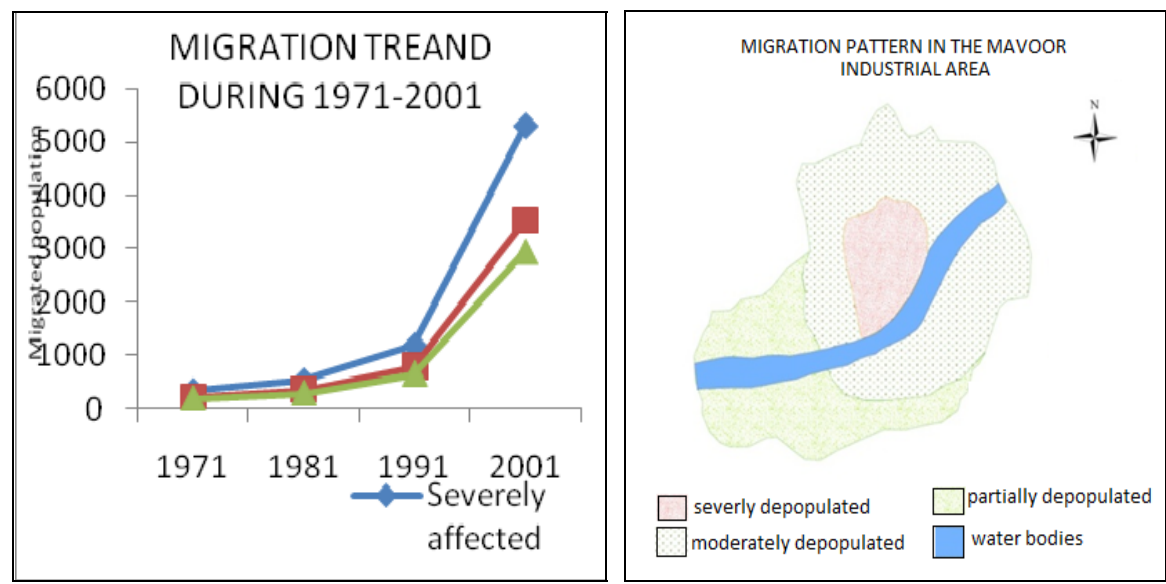

Figure 2. Characteristic features of the land use change in Chaliyar river basin 


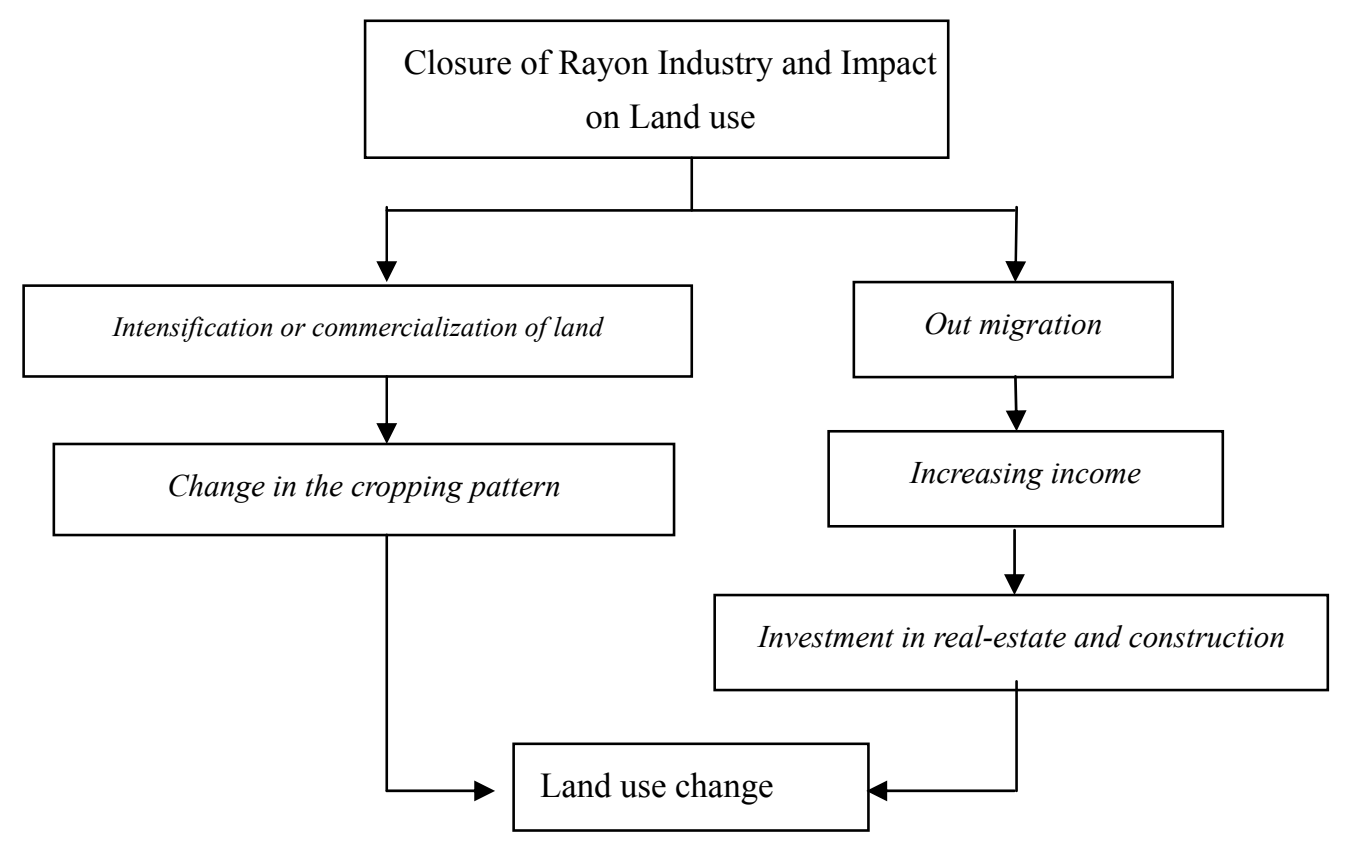

Figure 3. Conceptual Model of the Impact on Land Use Change

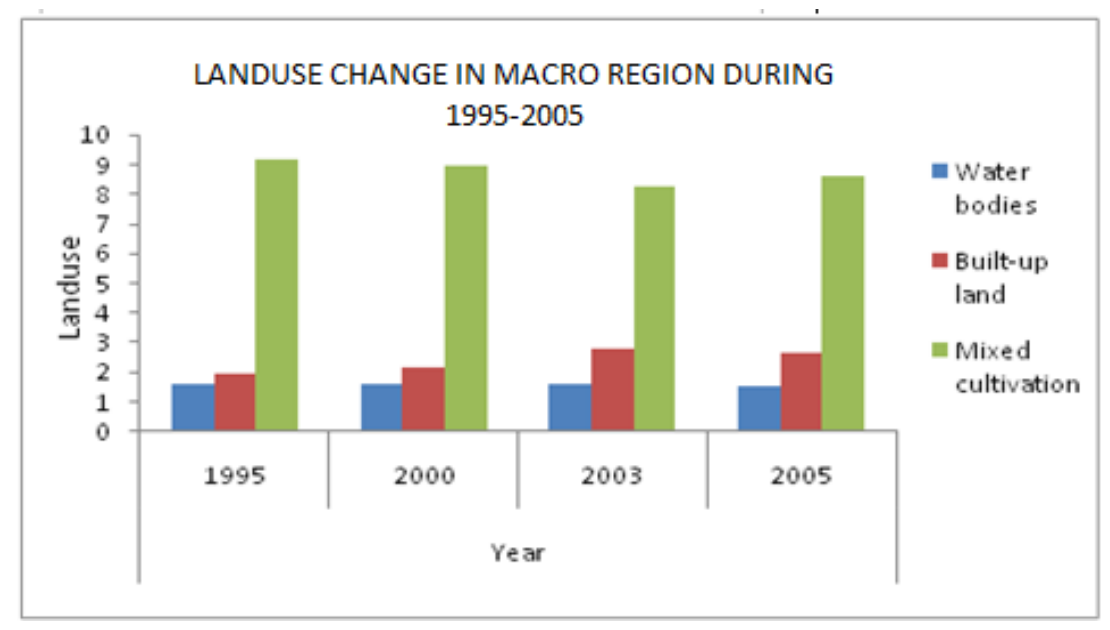

Figure 4. Land use land cover change in Chaliyar river basin since 1995-2005(sq.km) 

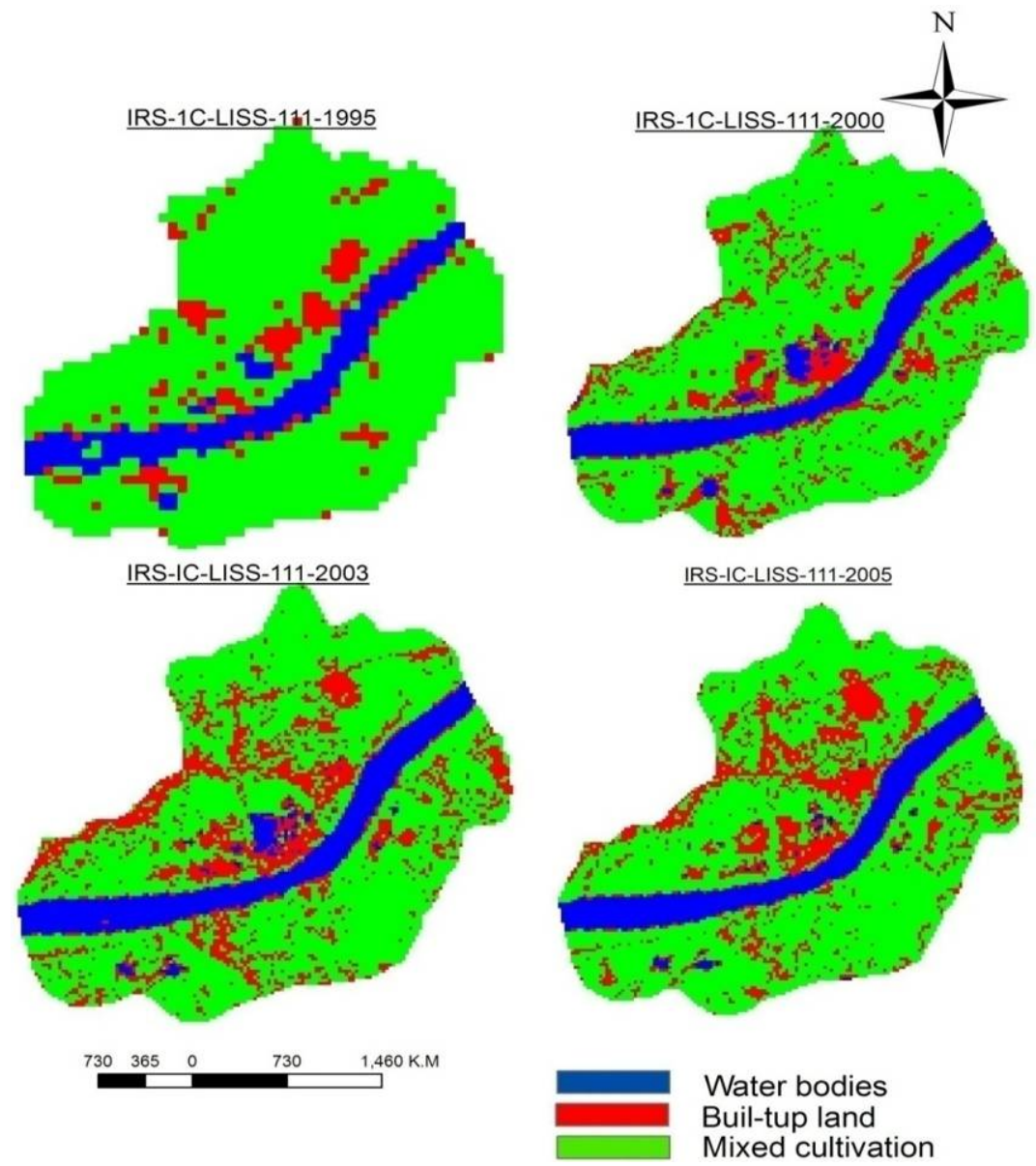

Figure 5. Temporal Variations the landuse changes in the Chaliyar river basin

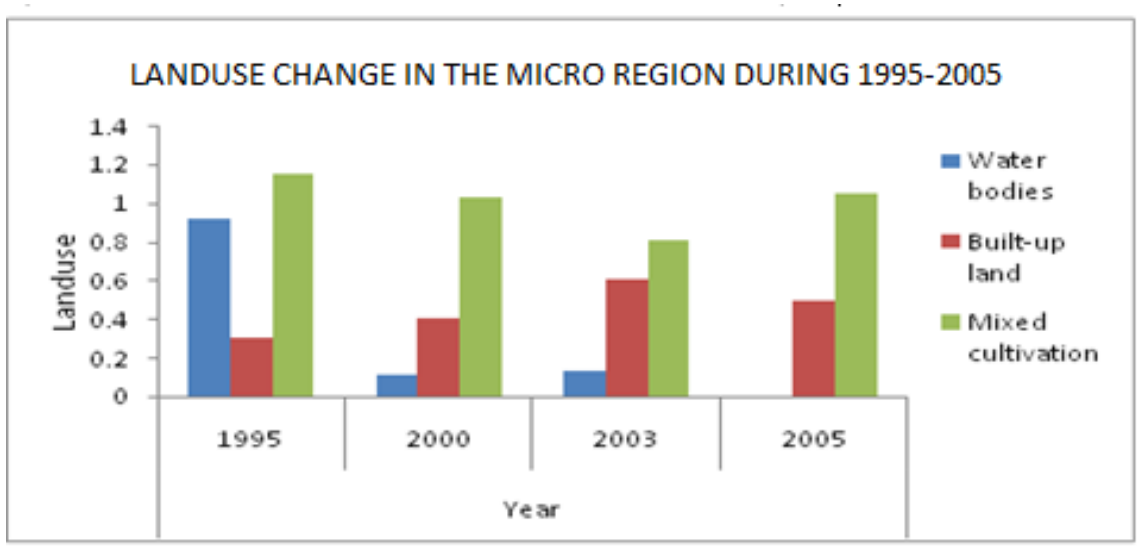

Figure 6. Landuse change on the micro part during 1995-2005 

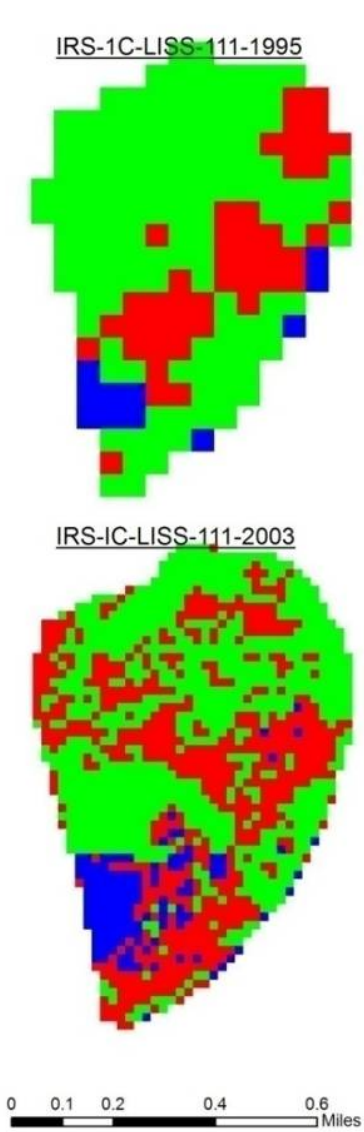
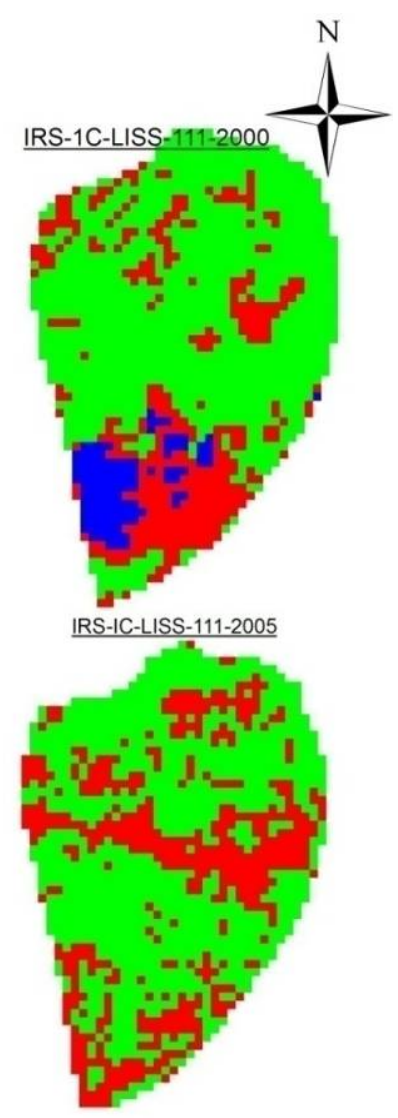

Water bodies

Buil-tup land

Mixed cultivation

Figure 7. Landuse change on the micro part of Chaliyar basin during 1995-2005 